\title{
Technepoieses and the White Buffalo Calf Woman
}

\section{Technepoïesis y el mito de la mujer-búfala blanca}

\author{
Jeffrey Hogrefe \\ Associate Professor, Architecture, \\ Humanities and Media Studies \\ (Pratt Institute, Brooklyn, N.Y. U.S.A)
}

Reception date: 16 0ctober 2016

Review date: 5 December 2016

To cite this article: Hogrefe, J. (2017): Technepoieses and the White Buffalo Calf Woman, Icono 14, volumen 15 (1), pp. 46-62. doi: 10.7195/ri14. v15i1.1025 


\section{Abstract}

We live in a post human world where the networks and systems that circle the globe have the potential to eclipse any individual or nation, supplanting the horizontal orientation of empire with a vertical orientation of cyberspace, which offers new autopoetic formations of individuals and communities in local expressions of the global. We can learn from the Oglala Lakota myth of the White Buffalo Calf Woman at a time when cyberspace carries the potential to marry an ancient technology, that allows for a total immersion of the body in an expanding time and space, with the newest technology for mapping coordinates on the level of the body. The paper takes an auto-ethnographic approach to Lakota Sioux practices as a complete technology; a technepoïesis that projects new possibilities for human interaction through anticipatory and tacit knowledge, which can be mapped onto puzzling situations to clear a path.

Key Words: Anticipatory - Embodied - Knowledge - Ground - Hanbleceya - Horizontal - Performative - Tacit - Vertical

\section{Resumen}

Vivimos en un mundo posthumano donde las redes y sistemas que circundan el globo tienen el potencial de eclipsar a cualquier individuo o nación, suplantando la orientación horizontal del imperio con la orientación vertical del ciberespacio, que ofrece nuevas formaciones autopoéticas de individuos y comunidades en las expresiones locales de lo global. Podemos aprender del mito Oglala Lakota de la mujer-búfala blanca en un momento en que el ciberespacio puede enriquecerse del potencial de unir tecnologías ancestrales que permiten una inmersión total del cuerpo en un tiempo y espacio en expansión con las tecnologías más nuevas que para cartografiar coordenadas a nivel corporal. El artículo adopta un enfoque auto-etnográfico de las prácticas de Lakota Sioux como una tecnología completa; una tecno-poiesis, que proyecta nuevas posibilidades de interacción humana a través del conocimiento anticipatorio y tácito, que puede ser asignado a situaciones desconcertantes para abrir caminos.

Palabras clave: Corpóreo - Conocimiento - Conexión con la tierra - Hanbleceya - Horizontal - Performativo - Previsor - Tácit - Vertical 
MONOGRÁFICO

\section{Introduction}

The Hanbleceya ritual described in these pages took place on an approach to the Appalachian Trail thirteen miles south of Harpers Ferry, West Virginia, seventy miles west of Washington, DC. The rebirthing ritual is an indigenous rite of passage for adolescents; one of the seven sacred Lakota Sioux ceremonies. I undertook it in middle age. There are people "on the hill" as old as 100. Some people stay up as long as three nights and four days. Mine takes place over two days and one night in early June. In addition to sparse clothing and isolation, in keeping with the tradition I go without food or water during the day preceding and the entire ceremony. I wear a star quilt as a protective cover since it represents the four stages of transformation for the initiate. The design of the blanket is a numerological device that defines the four vertical layers of consciousness-above the sky, in the sky, on the ground and below the ground. The design of the blanket represents the cosmology of the Black Hills of South Dakota, where the ceremonies were transmitted to the Lakota Sioux by the White Buffalo Calf Woman (White Lance, Why the Black Hills Are Sacred 2004, 12).

I stand on a designated ground that measures eight feet by eight feet--singing, dancing and praying. My body is to remain within the prescribed plot for the duration of the ceremony so that the spirits can guide the Hanbleceya and protect me from the chaos of the unknowable on the outside of the plot. The boundary between chaos and cosmos is defined by a string of prayer ties-four hundred and five tiny cloth satchels containing bits of tobacco leaf that I have crafted from my own hands in preparation for the ceremony--strung between four poles on the perimeter of the pad fashioned from red willow saplings that have been stripped of their bark. The poles mark the cardinal directions and acupuncture the ground to release the air and ground spirits, from west to north to east and south-black, red, yellow and white. Oriented vertically, horizontally, temporally and spatially, in the Hanbleceya I sing the Lakota song that invokes the four directions; I dance without ceasing while holding a pipe loaded with a mixture of red willow bark and tobacco that is secured by a plug of sage, on a designated ground that measures eight feet by eight feet. For each of the four directions I have crafted fifty prayer ties for the people and fifty for the spirits, which include the seven stars of the Big Dipper, the seven divisions of the 
Great Sioux Nation, the seven sacred ceremonies of the pipe, seven original Sundance songs, seven generations (past and future) and seven altars of the seven sacred mountains of the Black Hills, and for the seven directions-cardinal directions, sky, earth and heart-and an additional five for the altar. On the west side of the altar is a wooden bowl containing food offerings for the air spirits. A red satchel contains fresh earth from a mole hole for spirits that live in the earth.

These are the bare, concrete facts of the Hanbleceya, a ceremony which has provided an essential experience on the level of the body that expanded my capacity as a writer and teacher in the visual arts with a specialty in space and subjectivity-essentially, the study of the perceptual relationship of the body to its the surroundings that can lead to an awareness of the dynamic production of space and subjectivity. Exposure to the elements brings about an inner space that is ultimately sustaining -an autopoetic space, where the interior moves outward and surrounds the body as it perceives its outer shell looking back inside the inner body. Hanbleceya strips away language through an acceleration of the senses. The initiate relinquishes speech to the ancestor spirits that reside in, on, and around the ground, below the ground, sky and above the sky.

The Hanbleceya increases awareness of the sanctity of all matter and the interconnectedness of the human, non-human and post human networks in the millennial awakening of systems and networks encircling the globe that are stronger than any individual or groups of individuals. The human-centered humanism of the Enlightenment Project that gazes critically on the '0ther' as it divides the earth into governable parcels of land was at the foundation of the political systems that ultimately led to the continuing decline of Indigenous peoples. In the age of the post human where the network of systems that encircle the globe is becoming larger and more powerful than any individual or nation I will propose in this paper that it can be imagined that the Lakota Sioux ceremonies that are connected to the vertical orientation of the ground below; ground, sky and stars can present another way of being in the world.

The Lakota Sioux entered into the popular cultural imagination in the late nineteenth century with a defiant resistance to colonization and assimilation on the Great Plains through the leaders Crazy Horse, Sitting Bull and Red Cloud. They 
defeated the American cavalry in the signature 1876 Battle of the Little Big Horn, known to Lakotas as the Battle of the Greasy Grass and Custer's Last Stand, which was led by the Lakota warrior Crazy Horse, to protect the Black Hills from colonization, and they have preserved the ceremonies with a fealty to tradition that borders on the obsessive. Although Crazy Horse was subsequently killed by U.S. agents the following year and the reservation system was founded with the removal of the Lakota people from the Black Hills and with the banning of the ceremonies in 1883, Crazy Horse transmitted a prophecy to the people that the nations would be reunited in the seventh generation with the coming together under the sacred tree of life of black, red, yellow and white people to usher in a period of prolonged peace at the end of European American colonization.

The revival of the practices with the passage of the American Indian Freedom of Religion Act in 1978 has led to a steady increase in ceremonies on the reservations where the Lakota population was concentrated when they were forcibly removed from the Black Hills, and outward to other locations where they are calling for ceremonies in their dreams. This is the seventh generation. A people who turned inward for one hundred years have turned outward as nomadic medicine carriers. The intercessor for the Hanbleceya, Reed Red Kettle Brown is descended from an illustrious family of medicine people-his great grandfather Geoffrey Horn Chips was the medicine man who guided the vision that Crazy Horse received on Bear Butte, which led to the pyric victory in the Battle of the Little Big Horn. When he first led a Sundance the elders told him that the sky is bleeding and people will come. A revival of a peripatetic culture that once moved for thousands of miles in the middle of the continent in pursuit of buffalo has been transformed into a heterotopian culture led by Lakota speaking medicine carriers

such as Red Kettle Brown who arrive in remote places in the U.S. and Canada carrying the ancient implements of the Lakota Sioux ceremonies.

\section{Methods}

The paper presents an auto ethnography of indigenous practices that introduce anticipatory tacit knowledge tied to the land. Knowledge performed by indigenous people, and which has led to recent examples of environmental activism in the U.S.A. The approach to this article is consistent with indigenous critical theory 
and sets out to present and align indigenous practices with Western European philosophy and theory to stress the value of indigenous theory in contemporary situations.

\section{Discussion}

\subsection{The Decolonization of the Myth of the White Buffalo Calf Woman}

Central to this discussion is the myth of the White Buffalo Calf Woman, which orients the ceremonies in the landscape just described. The revival of the traditions has led to new interpretations, so that the myth acquires added shape and dimension as a prophecy for the indigenous future. Originally interpreted in English as a cautionary morality tale, the myth, as it is commonly told, centers on the journey of a pair of male warriors who are unable after days of hunting to locate food for their people on the barren plains. A beautiful woman of humanimal qualities appears dressed in white buckskins carrying a bundle. The first warrior is consumed by lust for the Calf Woman. She strikes him with a lightning bolt that zaps him into a skeleton eaten by snakes, vanquished for his bad thoughts (the word "bad" is used in accounts; see Powers 1982). The other warrior's modest approach is rewarded by the Calf Woman who brings his starving people the seven traditions of the Lakota Sioux, including the Hanbleceya, the Sundance and the sacred pipe rite used in all of the ceremonies.

Although there is some disagreement about the extent of the ceremonies, all of the versions of the myth agree that it provides the spiritual tools that the Lakota people required to survive on the Great Plains, hunting buffalo as their primary food source and shelter (see Black Elk, Lame Deer, Powers). The nomadic tribes consumed every part of the buffalo in an ecological system as they travelled. They gathered for annual Hanbleceya ceremonies in the spring, and the Sundance in the summer in the Black Hills so as to commemorate their dedication to the buffalo.

I would like to propose a postcolonial interpretation of the myth of the White Buffalo Calf Woman that repositions the story in the distinction between thanatos 
and eros-the death instinct and life. Under this critical lens, the first warrior represents the death instinct of the colonial usurper who, motivated by greed, would destroy the indigenous people for the sake of the minerals in their land. The privileging of sexual moralizing in the common translation of the story is perhaps evidence of the role of the Christian missionaries in the earliest translations of the Lakota myth --Black Elk, whose translation has provided the basis for all future critical work, was a devout Episcopalian. The second warrior represents the life instinct of the indigenous peoples, respectful of the landscape and of the ceremonies that can maintain and promote the land. The concept of the interrelatedness of all things that is found in the Lakota expression mitakuye oyasin-essentially everything is related-is critical to the myth, somehow resembling the posthuman concept of the networked system relationships in the cybernetic universe.

In this paper, I have been asked to reflect on techne and poiesis, two categories of knowledge set out by Plato and his student Aristotle in the fourth century BCE in relation to ancient mythology, the religious belief system of the Greeks (and later the Romans). The neologism technepoiesis can be presented as a transformative system of knowledge and as such, it can be compared to the belief-system implicit in the Lakota Sioux ceremonies discussed in this article. While I am sensitive that a comparison of Western and indigenous methods of thinking and practice might strain indigenous belief systems to meet externally imposed standards--the combination of techne and poiesis and the myth of the White Buffalo Calf Woman, who introduces practices for a total transformation of the body politic, is interesting for the reasons described below.

As epistemological systems, techne is essentially knowledge that comes through the hands and poiesis is essentially knowledge that comes through the voice that moves actuality into possibility through praxis. Techne is the etymological origin of technology. Poiesis, the origin of poetry. Knowledge for Aristotle was a possession to be acquired through careful study with his teachers. His scientific methodology would have regarded an immersive ceremony such as the Hanbleceya, as a barbaric practice. Yet it is the immersive nature of the Hanbleceya and the Sundance and the other traditions that the White Buffalo Calf Woman brought to the Ogala Lakota people that produce what could be regarded as a transdisciplinary union of 
techne and poiesis. Technepoiesis locates knowledge in the ground through metis or tacit knowledge of the indigenous that can be acquired in ceremony.

As I have indicated, the hand prepares the altar for the Hanblecha, and the voice transmits to the people the insights gained in the ritual. At the beginning of the ceremony the initiate is taken into the Inipi and asked to provide their rationale for pursuing the Hanbleceya. At the conclusion, they are asked to provide their insights from the experience. The Inipi is a dome shaped structure, heated with fired rocks doused with sacred water. These are known as sweat lodges, but I prefer the indigenous term Inipi which translates literally as "to live again."

\subsection{Anticipatory and tacit knowledge}

Arguably, Aristotle's concept of poiesis and techne when applied to the myth of the White Buffalo Calf Woman can be understood as the intuitive and tacit knowledge (metis) that indigenous practices offer to Western philosophical systems. The Aristotelian anticipatory logic used to deal with the external world is replaced by a sort of inner invisible knowledge that does not follow the usual ways (i.e. Euclidian) of contemplating the world. The horizontal axis of the book and the surveyor's transom and Euclidian right angle is replaced by the vertical axis of the below the ground, ground, sky and above the sky orientation of the circle.

The practices remind us that knowledge is performative, embedded in the ways people live their lives. It is something we do, not something we have. For this reason, the transmission must be performed, celebrated, ritualized collectively in specific practices, in connection with kinship regulation, with language and physical features of the landscape as well as with other "natural" phenomena. "Metis can be seen here as forms of knowledge embedded in local experience with the more general, abstract knowledge deployed by the state and its technical agencies." (Scott, 1998, 311). "Metis is, in fact, the "art of locality" (316), he adds.

The knowledge formation discussed in this paper is an example of this tacit, anticipatory knowledge of the Native American, previously theorized by Philippe Baumard in his Tacit Knowledge in Organizations. Baumard shows how tacit knowledge plays a 
central role in the learning process, although this occurs at an unconscious level. In the Hanbleceya, the initiate is detached from explicit reality so as to penetrate other levels of reality, including what psychoanalysis would call the unconscious and the Indigenous, a dream. Through the unconscious or dream the initiative receives insights or visions that are carried back to the people to assist them in the form of prophesies, such as the one the Crazy Horse presented. There are other prophesies such as the commonly circulated Hopi prophesy of the coming of the Internet as a spider-web covering the globe, which results in a reorientation of the earth from horizontal to vertical with the coming of the eagle landing on the moon. And the current time when the white buffalo calf will return with the ascendancy of women in positions of power.

\subsection{Transmission of knowledge}

This article, a simple technology, will provide a transmission of anticipatory, tacit knowledge as it was acquired through cognitive embodiment. In a diffused and fragmented world of heterotopias that have arisen through the discreet, fleeting and recombining spaces provided by cyberspace, the indigenous practices that I present here encourage inherent differences in race, class and gender, instead of a unifying modernity based on universalizing concepts that minimize differences in a world characterized by massive and volumetric glass walled accumulations of capital beside edge conditions of increasingly degraded poverty. Somewhat paradoxically, the interfaces provided by the digital age enable the original technology of the indigenous belief system, as it is presented in this article, to be transmitted to the cyberspace. Although it is certainly true that a virtual experience was essential to the experience that is presented in this article, it is also true that millions of Indigenous people are unable to connect in cyberspace due to extreme levels of poverty. Still, the Internet has enabled the Lakota people that I practice with to connect broadly both within and without the reservations via social media to expand their sphere of influence and mobilize political support in their struggles for survival. When I leave the Pine Ridge Reservation after the annual Sundance I still participate in the political life via Cangleska Luta Tiospaye site that brings local, particular knowledge of the reservation in all of its many facets into my screen in Brooklyn, New York, and connects us with the Tiospaye in the Potomac River Valley where the Hanbleceya takes place and to other sites in Kansas City and Albuquerque. 
In Modernity at Large, Arjun Appadurai, an area studies anthropologist, posits that the universalizing forces of modernity have been broken apart and excited by the technology of cyberspace. In Appadurai's postnational landscape, the social, political, cultural and symbolic forces that led to a modernity that provided agency for many people, has been reorganized into dynamic spatial configurations that combine the physical and virtual into what he refers to as "scapes"-from landscape, a unit of measurement of space in time. Appadurai's theory of rupture “...takes media and migration as its two major, and interconnected, diacritics and explores their joint effect on the work of the imagination as a constitutive feature of modern subjectivity," which "offer(s) new resources and new disciplines for the construction of imagined selves and imagined worlds." (Appadurai, 1996, 3).

For the purposes of his argument Appadurai organizes the scapes into five categories for the five largest units of data. These are ethnoscapes, for rapidly moving groups of "persons who constitute the shifting world in which we live," $(1996,33)$, technoscapes, "global configuration of technology [that] moves at high speeds across various kinds of impervious boundaries," $(1996,34)$ financescapes, "the disposition of global capital...at high speeds," $(1996,34)$ mediascapes, "imagecentered, narrative based accounts of strips of reality," $(1996,35)$ and ideoscapes, "concatenations of images ... specifically oriented to capturing state power." $(1996,36)$

The fact that a genuine experience that is rooted in a Stone Age practice is available to us today when it was not readily available to those living in the modernity of the middle of the twentieth century, is a product of the diffuse networks present in the postmodernity of the scapes; as I have received them and am now transmitting them via the screen I am now looking at as I write this article. With the benefit of the alliances that have taken place via the digital interfaces, I no longer write an anguished cry for a lost spiritual tradition, as a nineteenth century ethnographer among the Pacific Island natives would; nor a twentieth century modernist in the phenomenological tradition who bemoans the fate of the indigenous. Post Fordist, I write about a regained spiritual tradition that still remains in my bones from the earliest men and women, and which has been made available to me through the Internet of ideas. 
Writing fixes words to the page in an indelible way that is not as dynamic as speaking, which allows for performance to take place, and a community to be formed through exchanges that occur extemporaneously. I want to make it clear from the onset that I am presenting my experience within the constraints of writing, as a method of transferring an experience of knowledge that was conveyed to me via the oral tradition that Lakota Sioux practitioners follow. You will notice that there are not any photographs in this article. Photography is prohibited in the ceremonies that I took part in. Initially I suggested foolishly that I would try to record my experience in the Hanbleceya with a camera and a voice recorder, which was met by the collective bemusement of the spiritual guides. They chortled that my film and tapes would be blank. Red Kettle Brown gave me permission to write about the ceremonies in the seventh year of my practice. When I cautioned that my experiences were filtered through western philosophy and critical theory he indicated with a laugh that the role of the ceremonies was to enhance who I am in relationship to my own Indigenous past not to turn me into a Stone Age person who exists before the alphabet was invented. I have come to see that the ceremony is not a reenactment of a past event. It is an omnipresent event.

After the Hanblecha, I began to participate as a dancer in the Red Hoop Sundance in Wanblee, South Dakota that Red Kettle Brown leads as intercessor. Sundance is the central ceremony of the Lakota Sioux calendar-four days and four nights around a sacred tree on the new moon in August that marks the start of a new year. As a Sundancer I am an integral member of a Tiospaye that centers on Pine Ridge Reservation in the Badlands at Bear Creek in Wanblee, South Dakota and radiates out to other places through the interfaces that are now possible via the information superhighway. I began to Sundance after I saw myself in a sacrificial position during the Hanbleceya. Red Kettle Brown guided the Hanbleceya from a distance of over one thousand miles via a cell phone to the sponsors of the Hanbleceya. The altar was transmitted by Red Kettle's maternal grandmother Fanny Red Hoop, who was given the name Fanny in the Indian School in Carlisle, Pennsylvania, which is located less than a hundred miles from the site of the Hanbleceya. 


\subsection{Crying for a Vision}

With permission from those who have inherited and kept the traditions, I am writing principally because I am a trained observer, an author and a teacher, and the spirits have spoken to me in the way that I can write. Although I have followed Native American practices since I was a boy, when my mother drove me to Indian Y Guides where I learned to make moccasins and drums in response to vestigial traces of Shawnee blood on the matrilineal line.

I first visited Pine Ridge Reservation in 2001 in the aftermath of 9/11 and I was taken into ceremony by one teacher after another who together were able to guide my progression slowly over time. The practice that I followed was not easy for me to discuss or write about initially: it was a transformational practice, foreign to my way of thinking. When I finally could write I was pleasantly surprised by the ease with which the document was revealed on the page-an awe followed by dread that I now recognize as essential component of a spiritual experience which denies its expression even as it is being expressed. The mind resists what the spirit persists in revealing to the body: knowledge comes in through the spirit connecting to everything around it rather than the mind; it cannot be acquired, only received in the tradition of the White Buffalo Calf Woman. It's my understanding that the ground is only place where the language can fully express itself during the Hanbleceya. While on the ground in the Hanbleceya the capacity to speak and record in language is suppressed by the other ways in which knowledge can be transmitted. After being removed from the Hanblece$y a$, language stays on the ground for a new natal way of being has entered the heart.

The contrast of the senses that take place during the Hanbleceya is uncomfortable to my ordinary sense of what I think that I require to be in the world; not only physically but mentally and spiritually anguished in ways that I resisted mightily. For that reason, when referring to the Hanbleceya I prefer a literal translation of the Lakota word Hanbleceya, "Crying for a vision," to the English interpretation "vision quest." "Vision quest" signifies a possessive colonial mind that owns what it can see through a surveyor's transom that reaches out in a quest for new lands on the horizon. It shows the inability of translation to fully free the language of the burden of colonization. 
The Hanbleceya strips away thoughts for a humble mind that can barely see anything as it is visible to the eyes; activated through the tactile and aural senses as much as the visual or through an admixture of all of the senses-why distinguish them when they come in an onslaught of sensations? The privileging of visuality is a remnant of a colonial mentality that owned what it could survey through the eyes, and acquire through a conversion of force. The emphasis on crying highlights the ways in which the initiate emerges cocoon-like from a series of arduous physical, mental and spiritual trials with a new perception of the cosmos that comes about as the result of painstaking observance of the elaborate details of the ceremony. The mind resists what the spirit persists in revealing to the body-the indigenous practice can only be acquired through persistent practice in crying.

As the Hanbleceya, with its forced isolation, turns inward, the Sundance, with its circle of dancers and drummers and singers and supporters, turns outward to form a tiospaye that guides the politicization of the nations. Red Kettle Brown explained on our first meeting that, in keeping with the vision of Crazy Horse, his circle was to consist of representatives of white, black, red and yellow men and women and that the spirit of woman as transmitted by his Grandmother Red Hoop was to predominate in the Cangleska Luta tiospe-Red Hoop circle.

The way that the ceremonies survived into the twentieth century in the reservation system focused largely on masculine warrior culture in a racialized hierarchy of pure bloodedness which excluded women and many native and non-native men from participating in the ceremonies. When Red Kettle Brown began to Sundance in the 1980s he recalls that there were three Sundances on the Pine Ridge Reservation; two were conducted by the church. In 2016, I have learned anecdotally that there were approximately two hundred registered Sundances on Pine Ridge Reservation, which is only one of the largest of many reservations where the ceremonies have been revived. Red Kettle Brown subscribes to the belief that men have become weaker and women stronger in the contemporary period, and women are essential to the ceremonies, and to the future, as they were in the past when the ceremonies were brought to the people by a woman. 


\subsection{Indigenous knowledge and environmental activism: the Dakota controversy}

Although I don't want to in any way overlook the devastating poverty of the Pine Ridge Reservation where the traditions described in this paper have been sheltered and are being disseminated, it is true that a revival of a nomadic culture that once moved for thousands of miles in the middle of the continent in pursuit of buffalo has been transformed into a heterotopian culture that finds Lakota speaking Oglala Sioux medicine carriers, such as Red Kettle Brown, emerging in many of the states with cellphones and a rectangular wooden case containing the pipes and other medicine that they have carried out into the world.

The inipi or sweat lodge, described above, can be erected anywhere with access to water and a Hanbleceya can be held on any piece of land. However, certain places contain higher concentrations of spiritual energy. The Black Hills of South Dakota contain the seven sacred altars of the Oglala Lakota speaking people. Oglala translates as "scatters my people" in Lakota, since the Lakota were historically nomadic Buffalo hunters who would return annually to the Black Hills, and are today nomadic spiritual guides whose guidance has informed many remote communities with new transformative possibilities.

The Lakota believe in the circle and verticality exemplified in the myth of the White Buffalo Calf Woman instead of the square and horizontality of the Euclidian Westerner. The fulfillment of Crazy Horse's prophesy can be seen in the network of circles that have spanned out from the Sundance Tiospayes such as the one described in this paper to generate the groundswell of support for the Sacred Stone Circle that led to the environmental activist protest last year on Standing Rock Reservation, which attracted international attention to the Dakota controversy.

The North Dakota camp is located on a historic sacred site where ancient tribes held their annual Sundance. It is also where the sacred medicine rock is located that will tell the future. Under the banner, mni wiconi (water is life) the water protectors gathered on the sacred ground to object to the construction of a pipeline that would transfer fracked oil from the Bakken 0il Fields through a pipeline that would pass 
underneath the Missouri River as well as under part of Lake Oahe near the Standing Rock Reservation, threatening the region's clean water and ancient burial grounds.

The Dallas-based Energy Transfer Partners' Dakota Access Pipeline, the construction company building the pipeline, is commonly known as Dakota Access Pipeline, from which the water protectors derived the hashtag \#NoDAPL that appeared in thousands of twitter feeds and on posters and other forms of mediated images in public demonstrations. Standing Rock elder LaDonna Brave Bull Allard and a group of women established a camp as "a center for cultural preservation and spiritual resistance to the pipeline." (Sacred Rock Camp website n.p.) The word spiritual grounds the protest in ceremony. Brave Bull Allard presented herself as a historian who has, "the roots of the past growing under her feet," that led to the encampment because it was threatening the water supply and the ancestral burial grounds. (Brave Bull Allard).

Although largely ignored by mainstream media, the Sacred Stone Camp attracted international recognition through social media sites which created a flash mob effect that drew thousands of water protectors from all of the world to the remote site and the support of indigenous people from as far away as New Zealand and Australia. Bravebull Allard emphasized that they were not protestors, they are protectors. At the end of 2016, the lobbying action of these water protectors led to a reversal of an earlier decision by the Army Corps of Engineering which blocked the construction of the pipeline at the site while a study takes place.

\section{Conclusions}

For the most part, the Lakota Sioux ceremonies described above survived into the twentieth century as exotic feats of masculine bravado in a racialized hierarchy that privileged purebloods. White Catholic and Episcopal Church controlled the ceremonies and the educational system on the reservation. In contemporary practices, women are essential to the ceremony, and encouraged into the inner circle. Ceremonies are conducted with a renewed fealty to the myth of the White Buffalo Calf Woman. Once an important aspect of the abolitionist landscape and a remapping of the landscape on the northern edge of the Mason-Dixon Line at the 
intersection of the Potomac and Shenandoah rivers and the Appalachian Mountains where my Shawnee ancestors resided, the revival of the Native American ceremonies are taking new directions. Since the 1980s several Lakota medicine men, including Red Kettle Brown, have traveled to the Potomac River Valley where the Hanbleceya described herein took place in response to invitations from groups of people who have been led in their own dreams to revive the practices.

Thus, the regenerative project of Hanbleceya seeks to open new spatial and temporal dimensions through dancing and sacrificing, and the potency of the spirits that reside in the animals, minerals, the nonhuman and the posthuman. It activates the spirit, heightens awareness, increases mental agility and provides an immanent understanding of one's integral role in a cosmological system. It is both poiesis and techne-the making of Hanbleceya and the making of language and knowledge that resides on the ground.

Environmental activism has found a new center in the ceremonies of the NativeAmerican and Lakota Sioux, which locate knowledge and language in the ground through self-sacrifice. The ceremonies try to reverse the trauma of imprisonment in the reservation, recreating new ways of being in the land and new ways of gathering both on and off the reservation.

The myth of the White Buffalo Calf Woman is still potent in the lives of Lakota speaking people. The demonstration that has been staged at Standing Rock Reservation in North Dakota to protest the Dakota Pipeline is exemplary of the return of the myth. It provides an example of the circulation of indigenous anticipatory and tacit knowledge. The dirty energy of the fracked oil has been vanquished, at least for now, like the greedy warrior turned into a skeleton filled with snakes by the Calf Woman, possibly concluding seven generations of pollution and degradation. Although still struggling mightily under the gross accumulation of effects of poverty that is passed down generationally, the Lakota-speaking Indigenous of the North American Great Plains have emerged with a renewed powerfully networked system of belief; from a horizontal to a vertical pathway, and through a knowledge that is performative and embedded in the way that people live, and potentially. 


\section{References}

Appadurai. Arjun. (1996). Modernity at Large: Cultural Dimensions of Globalization. Minneapolis: University of Minnesota Press.

Aristotle: Episteme and Techne https://plato.stanford.edu/entries/episteme-techne/ Aristotle: Poeisis https://sites.google.com/site/praxisandtechne/Home/architecture/ knowledge/episteme

Baumard, Philippe (1999). Tacit Knowledge in Organizations. London, UK, Sage Publications,

Black Elk, Nicholas (Author) with John G. Neihardt (Collaborator) (1988/1932), Black Elk Speaks: Being the Life Story of a Holy Man of the Oglala Sioux as told through John G. Neihardt, Lincoln, NE., U.S.A: University of Nebraska Press, Byrd, Jodi. (2011). The Transit of Empire. Minneapolis: University of Minnesota Press.

La Donna Bravebull Allard by Lee Stocking (2016) https://www.youtube.com/ watch?v=Z7FVRprI6co

Lame Deer, John (Fire) (1972). The Story of the Buffalo Calf Woman. New York, NY, USA: Simon and Schuster. https://www.manataka.org/page798.html

Powers, William K. (1982). Oglala Religion. Lincoln NE., U.S.A: University of Nebraska Press.

Sacred Stone Camp website http://sacredstonecamp.org/

Scott, James C. (1998). Seeing Like a State How Certain Schemes to Improve the Human Condition Have Failed, New Haven, CT, U.S.A: Yale University Press.

TheProphecyofCrazyHorsehttps://www.pinterest.com/pin/490470215648809613/ Wilson, Pamela and Stewart, Michelle (Eds.) (2008) Global Indigenous Media. Durham, N.C., U.S.A: Duke University Press.

White Lance, Francis. (2004). Why the Black Hills Are Sacred: A Theory of the Lakota Sundance. Ancestors Incorporated: Rapid City, SD, U.S.A. 